\title{
Bioactive isocedrenes from Perezia multiflora
}

Bourgeade-Delmas S. ${ }^{1}$, Andre-Barres C. ${ }^{2}$, Lucas J. ${ }^{1}$, Trinel M. ${ }^{1}$, Castillo Pareja D.H. ${ }^{3}$, Jullian V.1,3

\author{
Affiliation \\ ${ }^{1}$ UMR 152 Pharmadev, Université de Toulouse, IRD, UPS, France \\ ${ }^{2}$ UMR 5068 LSPCMIB, Université de Toulouse, CNRS, UPS, France \\ ${ }^{3}$ Laboratorios de Investigación y Desarrollo, Facultad de Ciencias y Filosofía, Universidad \\ Peruana Cayetano Heredia, Lima 15102, Peru
}

\section{Correspondence}

Dr. Valérie Jullian, UMR 152 Pharmadev, Université de Toulouse, IRD, Faculté des sciences pharmaceutiques, 35 chemin des maraichers, 31069 Toulouse Cedex France. E-mail : valerie.jullian@ird.fr Phone : +33 562256886

\begin{abstract}
Four isocedrenes were isolated from an ethanolic extract of Perezia multiflora by bioguided fractionation. One compound is new and three of them were already described in the literature. For two of them, we proposed a revision of their 3D structures bases on molecular modeling studies using DFT-NMR calculations. Antiparasitic activity of the four compounds was evaluated using in vitro culture of Plasmodium falciparum and axenic amastigotes of Leishmania amazonensis. Toxicity against mouses macrophages J774A.1 or THP-1 cells was also evaluated. Compounds displayed good antiparasitic activity, but a weak selectivity.
\end{abstract}




\section{Key words}

Perezia multiflora, isocedrene, sesquiterpenes, Plasmodium, Leishmania

\section{Introduction}

Perezia multiflora (Humb. \& Bonpl.) Less. (Asteraceae) is a small herb growing in the highlands of andean mountains (3800-4500m) in Peru, Bolivia, Chile, Argentina, Ecuador, Colombia. In Peru, the plant is sold as fresh plant on andean markets and is very popular against cough, bronchitis, fever.

Isocedrenes are sesquiterpenes first described in P. multiflora and Proustia pyrifolia [1] by Bohlman, and then also in Trixis wrightii and T. inula [2]. Further studies have confirmed the occurrence of this squeleton in various genera, like Jungia [3], Moscharia [4], Pleocarphus [5], Acourtia [6], all belonging to the tribe Nassauviineae, subfamily Mutisioidaea in the Asteraceae family [7]. The name isocedrene was first proposed by Bohlman because this squeleton was similar to this of $\alpha$-cedrene, with a methyl shifted from C-3 to C-5 [1]. However, a biogenetical relationship between $\alpha$-cedrene and isocedrene is unlikely, and isocedrene is more probably formed from a cyperene squeleton [7]. Therefore, some authors proposed to use the name trixane instead of isocedrene [8-11].

In our hands, ethanol extract from aerial part of $P$. multiflora displayed interesting activity against in vitro culture of the parasite Plasmodium falciparum. In this work, we describe the bioguided isolation of 4 isocedrenes sesquiterpenes (1-4), and their evaluation against $P$. falciparum, Leishmania infantum axenic amastigotes and macrophages. One isocedrene is new, and we propose a revision of the previously published structures of two of them, based on careful examination of their NMR data and their comparison with computed ones. 


\section{Results and discussion}

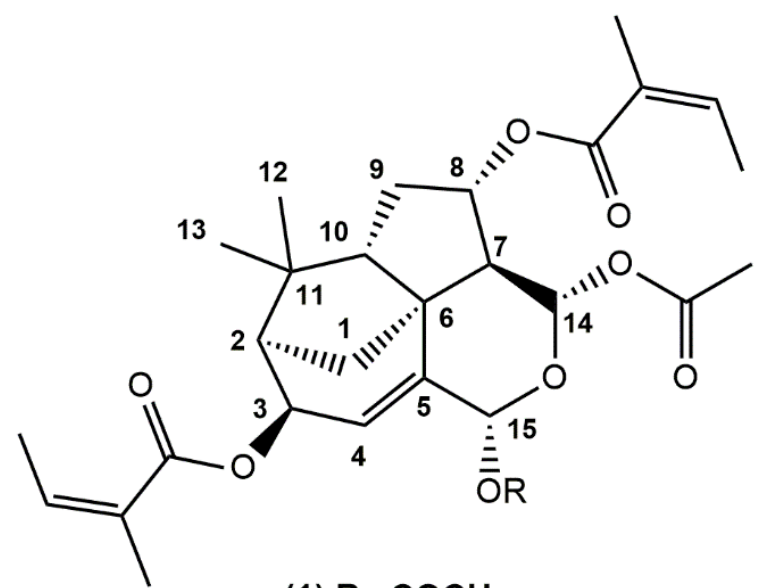

(1) $\mathrm{R}=\mathrm{COCH}_{3}$

(2) $\mathrm{R}=\mathrm{CH}_{3}$

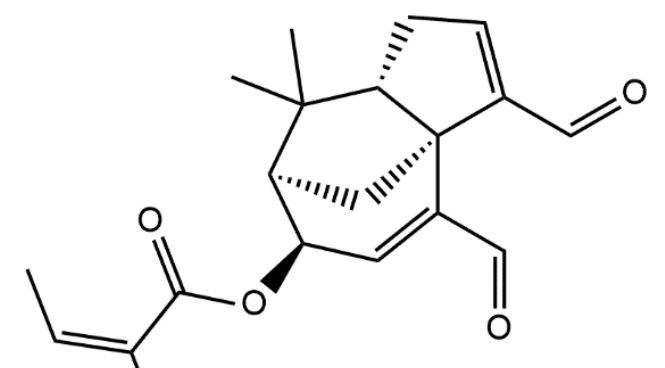

(4)

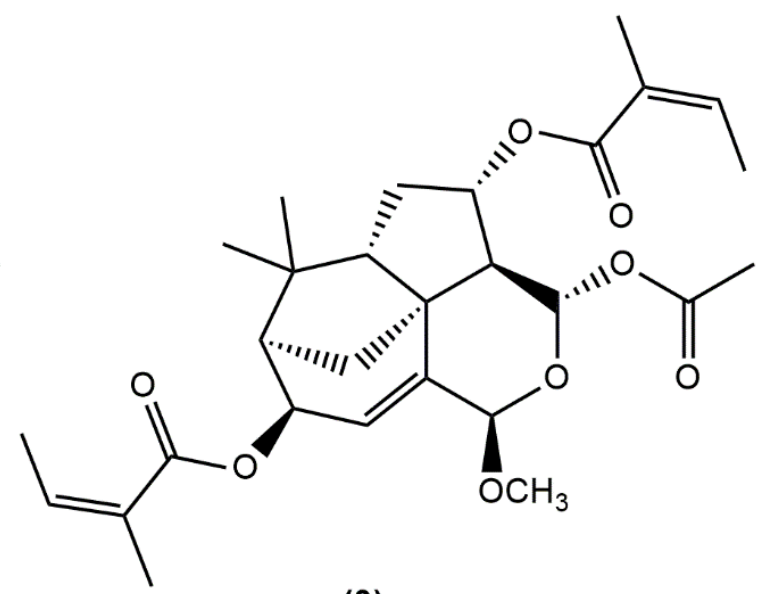

(3)

Fig. 1 Isocedrenes isolated from P. multiflora

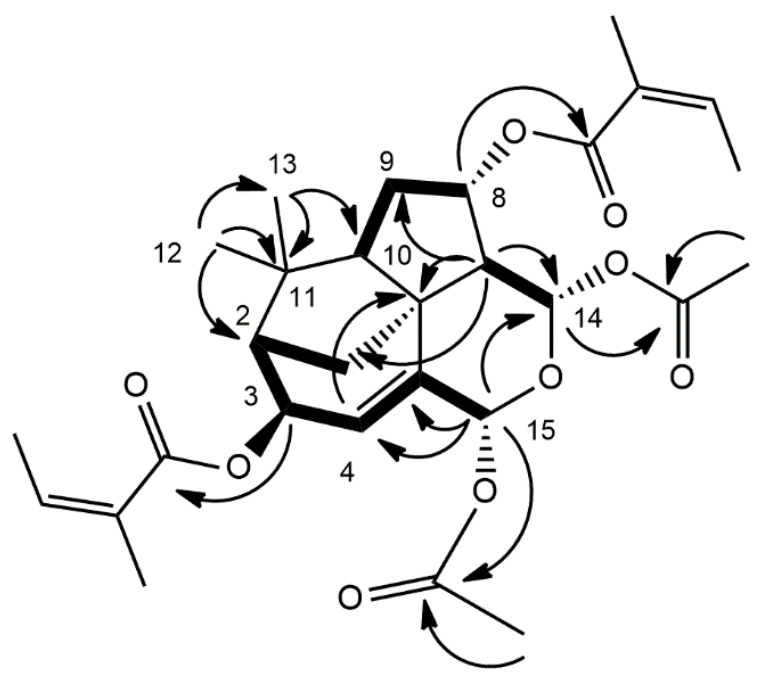

Fig. 2 COSY and HMBC correlations for compound 1 


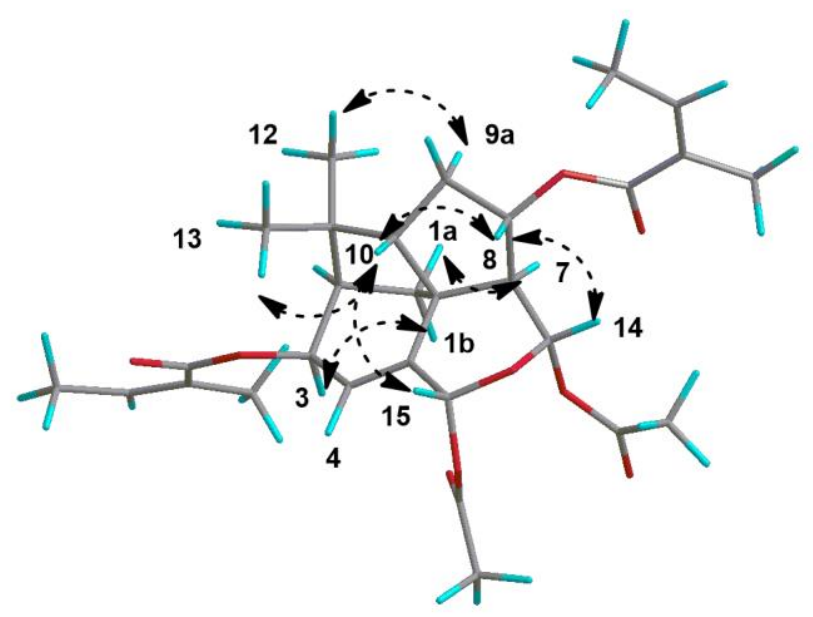

Fig. 3 Key NOESY correlations for compound 1

Compounds 1-4 were isolated from the ethanol extract of the aerial parts of $P$. multiflora by bioguided fractionation.

Compound 1 was isolated as colorless oil. Its molecular formula was established as $\mathrm{C}_{29} \mathrm{H}_{38} \mathrm{O} 9$ by positive HRESIMS $\left(\mathrm{m} / \mathrm{z} 548.2856,\left[\mathrm{M}+\mathrm{NH}_{4}\right]^{+}\right)$and showed 11 indices of hydrogen deficiency. Careful examination of 2D-NMR spectra allowed us to determine the planar structure, and to attribute all ${ }^{1} \mathrm{H}$ and ${ }^{13} \mathrm{C}$ NMR signals. The two methyl singulets at $\delta_{\mathrm{H}}$ 0.74 and 1.19 present $\mathrm{HMBC}$ correlations with one another and carbon signals at $\delta_{\mathrm{C}} 43.3(\mathrm{C})$, $52.8(\mathrm{CH}), 60.5(\mathrm{CH})$ which are typical of a gem-dimethyl group and allow to attribute $\mathrm{C}-11$, C-2 and C-10. ${ }^{1} \mathrm{H}-{ }^{1} \mathrm{H}$ COSY correlation between $\mathrm{H}-2\left(\delta_{\mathrm{H}} 2.03, \mathrm{~m}\right)$ and the signal at $\delta_{\mathrm{H}} 5.96$ allows to attribute $\mathrm{H}-3$. The position of the olefinic methine proton at $\delta_{\mathrm{H}} 5.49$ (q, $J=2.0 \mathrm{~Hz}$, $\mathrm{H}-4)$ was deduced by vicinal ${ }^{1} \mathrm{H}-{ }^{1} \mathrm{H}$ COSY correlation with $\mathrm{H}-3$, and long-range ${ }^{1} \mathrm{H}-{ }^{1} \mathrm{H}$ COSY correlation of $\mathrm{H}-3$ and $\mathrm{H}-4$ with the signal at $\delta_{\mathrm{H}} 6.92(\mathrm{dd}, J=2.8,2.0 \mathrm{~Hz})$ allowed us to attribute H-15. This was confirmed by HMBC correlations between H-15, C-4, and C-5. Substitution of $\mathrm{C}-15\left(\mathrm{CH}, \delta_{\mathrm{C}} 87.5\right)$ by an acetoxy group is confirmed by the HMBC correlation between $\mathrm{H}-15$ and a carbonyl at $\delta_{\mathrm{C}} 169.5$, and the HMBC correlation of this latter signal with a methyl singulet at $\delta_{\mathrm{H}}$ 1.59. Starting from $\mathrm{H}-10(1.72, \mathrm{~m})$, successive ${ }^{1} \mathrm{H}-{ }^{1} \mathrm{H}$ COSY correlations between signals at $\delta_{\mathrm{H}} 1.32(\mathrm{~m}), 2.09(\mathrm{~m})$, and $\delta_{\mathrm{H}} 5.20(\mathrm{ddd}, 10.5,8.9,5.9)$ allowed their 4 
attribution as $\mathrm{H}-9 \mathrm{a}, \mathrm{H}-9 \mathrm{~b}$ and $\mathrm{H}-8$ respectively. $\mathrm{HMBC}$ correlation of $\mathrm{H}-9 \mathrm{~b}$ with a methine signal at $\delta_{\mathrm{C}} 49.5$ positioned C-7, and ${ }^{1} \mathrm{H}-{ }^{1} \mathrm{H}$ COSY correlation between $\mathrm{H}-7\left(\delta_{\mathrm{H}} 2.09\right)$ and a signal at $\delta_{\mathrm{H}} 6.45(\mathrm{~d}, J=1.4 \mathrm{~Hz})$ identified $\mathrm{H}-14$. HMBC correlation of $\mathrm{H}-14$ with a carbonyl at $\delta_{\mathrm{C}} 168.5$, and the HMBC correlation of this carbonyl with a methyl singulet at $\delta_{\mathrm{H}} 1.70$ positioned an acetoxy substituent on C-14. The ethoxy link between C-14 and C-15 is suggested by the chemical shifts of $\mathrm{H}-14$ and $\mathrm{H}-15$, typical of acetalic protons, and by HMBC correlation between $\mathrm{H}-15$ and C-14. HMBC correlation between a quaternary carbon at $\delta_{\mathrm{C}} 47.5$ and $\mathrm{H}-4(5.49, \mathrm{q}, J=2.0 \mathrm{~Hz})$ and $\mathrm{H}-7$ or $\mathrm{H}-9\left(\delta_{\mathrm{H}} 2.09\right)$ indicates the central position of C-6 $\left(\delta_{\mathrm{C}}\right.$ 47.5), and the isocedrene structure is closed by the attribution of $\mathrm{H}-1 \mathrm{a}\left(\delta_{\mathrm{H}} 1.81\right)$ thanks to its COSY correlation with $\mathrm{H}-2\left(\delta_{\mathrm{H}} 2.03\right)$, and HMBC correlation between C-1 $\left(\delta_{\mathrm{C}} 44.5\right)$ and $\mathrm{H}-7$ $\left(\delta_{\mathrm{C}} 2.09\right)$. Signals typical of two angelate moieties are also present in the $1 \mathrm{D}$ and $2 \mathrm{D}$ spectra. HMBC correlations between 2 carbonyl signals $\left(\delta_{C} 166.9\right.$ and 167.0) belonging to these angelate with $\mathrm{H}-3$ and $\mathrm{H}-8$ positioned the angelate substituents on $\mathrm{C}-3$ and $\mathrm{C}-8$. This planar structure, as well as the ${ }^{1} \mathrm{H}$ NMR spectra were identical to these already described by Bohlman for 3-angeloyl-8-angeloyloxyproustianol [1], however, the published 3D structure was not coherent with our NMR data (coupling constants and NOESY), and prompted us to propose a revised 3D structure. Bohlman's structure was not coherent with the NOE effects observed between H-8 and H-14, and between H-8 and H-10. Only a 8-angeloyl and a 14-acetoxy both in $\alpha$ position could explain these NOE effects. A $\beta$ configuration for the 3 -angeoyl moiety is confirmed by the observed NOE effect between $\mathrm{H}-3$ and $\mathrm{H}-1 \mathrm{~b}$, and this allowed us to discriminate between $\mathrm{H}-1 \mathrm{a}$ and $\mathrm{H}-1 \mathrm{~b}$. The NOE effects between $\mathrm{H}-15$ and $\mathrm{H}-10$ allowed us to determine the C-15 configuration. Furthermore, the NOE effects observed between $\mathrm{H}_{3}-12$ and H-9a and $\mathrm{H}_{3}-13$ and $\mathrm{H}-10$ allowed us to discriminate between $\mathrm{H}_{3}-12$ and $\mathrm{H}_{3}-13, \mathrm{H}-9 \mathrm{a}$ and $\mathrm{H}-$ $9 b$. 
The absolute configuration proposed (Fig. 1) was coherent with a biosynthetic origin from a (-)-cyperene squeleton. It is also coherent with the absolute configuration of natural trixanolides determined by Mosher's method [11,12], and by ECD analysis supported by theoretical calculation [10]. Furthermore, the ECD spectra of compound $\mathbf{1}$ showed the same shape as these of previously reported trixanes [10]. Therefore compound $\mathbf{1}$ could be identified as $\quad(2 R, 3 R, 6 S, 7 S, 8 S, 10 S, 14 S, 15 R) \quad 14,15$-diacetoxy $\quad 3,8$-diangeloyloxy, 14-15-epoxy-4isocedrene.

Compound 2 was isolated as a colorless oil. Its molecular formula was established as $\mathrm{C}_{28} \mathrm{H}_{38} \mathrm{O}_{8}$ by positive HRESIMS (m/z 525.2457, $\left.[\mathrm{M}+\mathrm{Na}]^{+}\right)$and showed 10 indices of hydrogen deficiency. The ${ }^{1} \mathrm{H}$ and ${ }^{13} \mathrm{C}$ NMR data of 2 , as well as the 2D NMR spectra, were similar to those of 1, except for the disappearance of the signals of an acetoxy moiety, and the appearance of signals of a methoxy group $\left(\delta \mathrm{H} 3.27, \mathrm{~s}, \delta \mathrm{C} 55.5, \mathrm{CH}_{3}\right)$. The latter was positioned on $\mathrm{C}-15$, based on the the HMBC correlation of the methoxy protons with the carbon at $\delta \mathrm{C}$ 96.5. This latter signal could be attributed to $\mathrm{C}-15$ because of the ${ }^{1} \mathrm{H}-{ }^{1} \mathrm{H}$ COSY correlation between the proton at $\delta \mathrm{H} 4.96(\mathrm{dd}, J=2.7,1.9 \mathrm{~Hz}, \mathrm{H}-15)$ and the proton at $\delta \mathrm{H} 5.99(\mathrm{dt}, J=4.8$, 2.5 Hz, H-4). NOESY correlations and coupling constants were similar to those of $\mathbf{1}$, as well as ECD spectra. Therefore compound 2 could be identified as $(2 R, 3 R, 6 S, 7 S, 8 S, 10 S, 14 S, 15 S)$ 14-acetoxy, 3,8-diangeloyloxy, 14-15-epoxy, 15-methoxy-4-isocedrene. This is the first occurrence of this compound in the literature.

Compound 4 was isolated as a colorless oil. Its molecular formula was established as $\mathrm{C}_{20} \mathrm{H}_{24} \mathrm{O}_{4}$ by positive HRAPCIMS (m/z 329.1742, $\left.[\mathrm{M}+\mathrm{H}]^{+}\right)$and showed 9 indices of hydrogen deficiency. Analysis of ${ }^{1} \mathrm{H}$ and ${ }^{13} \mathrm{C}$ NMR data, as well as the 2D NMR spectra allowed us to establish the structure of $\mathbf{4}$. This compound was first described by Bohlman as the product of the saponification of a natural isocedrene isolated from Proustia pyrifolia [1], and ${ }^{1} \mathrm{H}$ NMR 
data matched with published ones. This compound may therefore be an artefact and the result of the hydrolysis of $\mathbf{1 , 2}$ or $\mathbf{3}$ during the purification on silica gel.

Compound $\mathbf{3}$ was isolated as a colorless oil. Its molecular formula was established as $\mathrm{C}_{28} \mathrm{H}_{38} \mathrm{O}_{8}$ by positive HRESIMS $\left(\mathrm{m} / \mathrm{z} 525.2458,[\mathrm{M}+\mathrm{Na}]^{+}\right)$and showed 10 indices of hydrogen deficiency. ${ }^{1} \mathrm{H}$ NMR data matched with published one for an isocedrene isolated from P. runcinata but again, the published structure was not consistent with our data, especially with the NOESY correlations [13].

Analysis of ${ }^{1} \mathrm{H}$ and ${ }^{13} \mathrm{C}$ NMR data, as well as the 2D NMR spectra indicates that compound $\mathbf{3}$ was a diastereomer of compound $\mathbf{2}$. The most striking differences on the ${ }^{1} \mathrm{H}$ spectra were the chemical shifts of the $\mathrm{H}-1 \mathrm{a}, \mathrm{H}-1 \mathrm{~b}$, and $\mathrm{H}-10$ protons and the coupling constants of the H-14 and H-15 protons. The strong difference between the coupling constant between $\mathrm{H}-14$ and $\mathrm{H}-7$ (1.7 Hz for compound $\mathbf{2}$ and $7.0 \mathrm{~Hz}$ for compound $\mathbf{3}$ ) prompted us to describe $\mathbf{3}$ as an epimer of 2 with opposite configuration in C-14. However, this structure was not consistent with the strong NOE effect observed between H-14 and H-8. The isocedrene structure could present different conformations due to the conformational flexibility of the tetrahydropyrane ring, which influences the geometry around C-14 and C-15. For compound $\mathbf{1}$ and $\mathbf{2}$ the data matched with a conformation were $\mathrm{H}-14$ and $\mathrm{H}-15$ were both pseudo-equatorials. For compound 3, NMR data could match with the structure of the epimer of $\mathbf{2}$ in C-15, but with a different conformation of the tetrahydropyrane ring, were $\mathrm{H}-14$ would be pseudoaxial and $\mathrm{H}$ 15 pseudoequatorial. Therefore, it seemed to us necessary to determine the major conformers contributing to the structure of $\mathbf{1}, \mathbf{2}$, and $\mathbf{3}$ more accurately. Then calculation of the NMR data corresponding to these conformers, and comparison with experimental spectra would permit to evaluate the relevance of the structures we proposed for the three compounds.

For each compound, the conformers were modeled by DFT, using Gaussian 09 at the B3LYP/6-31+G(d,p) level in the gas phase. Frequencies calculations were performed on the 
optimized geometries at $298 \mathrm{~K}$, showing all positive frequencies and allowing evaluation of the enthalpies of the minima.

${ }^{13} \mathrm{C}$ NMR and ${ }^{1} \mathrm{H}$ chemical shift calculations were then performed using the GIAO NMR method with B3LYP/6-31+(d,p) and using the chloroform polarizable continuum model (PCM) on optimized geometries at the B3LYP/6-31+G(d,p) level in the gas phase. Isotropic shielding constants $(\sigma)$ for the ${ }^{13} \mathrm{C}$ nucleus and ${ }^{1} \mathrm{H}$ were transformed in chemical shifts $(\delta)$ using linear regression procedure proposed by Tantillo [14]. The contribution of each conformer in the constitution of the overall spectrum was based on Boltzmann conformational analysis.

Optimized geometries and calculated values on major conformers of compounds $\mathbf{1}$ and 2 match with their experimental data, which were also recorded in $\mathrm{CDCl}_{3}$. Detailed calculations and ${ }^{1} \mathrm{H}$ NMR simulated spectra of compounds $\mathbf{1}$ and $\mathbf{2}$ are consigned in tables SI.1-SI.6 and figures SI.1-SI.2 of the supporting informations section.

Concerning the compound 3 the four isomers corresponding to the two possible configurations of $\mathrm{H}-14$ and $\mathrm{H}-15$ were considered, and for each structure, the two conformations (A and B) of the tetrahydropyrane ring were modeled (Fig. 4). 


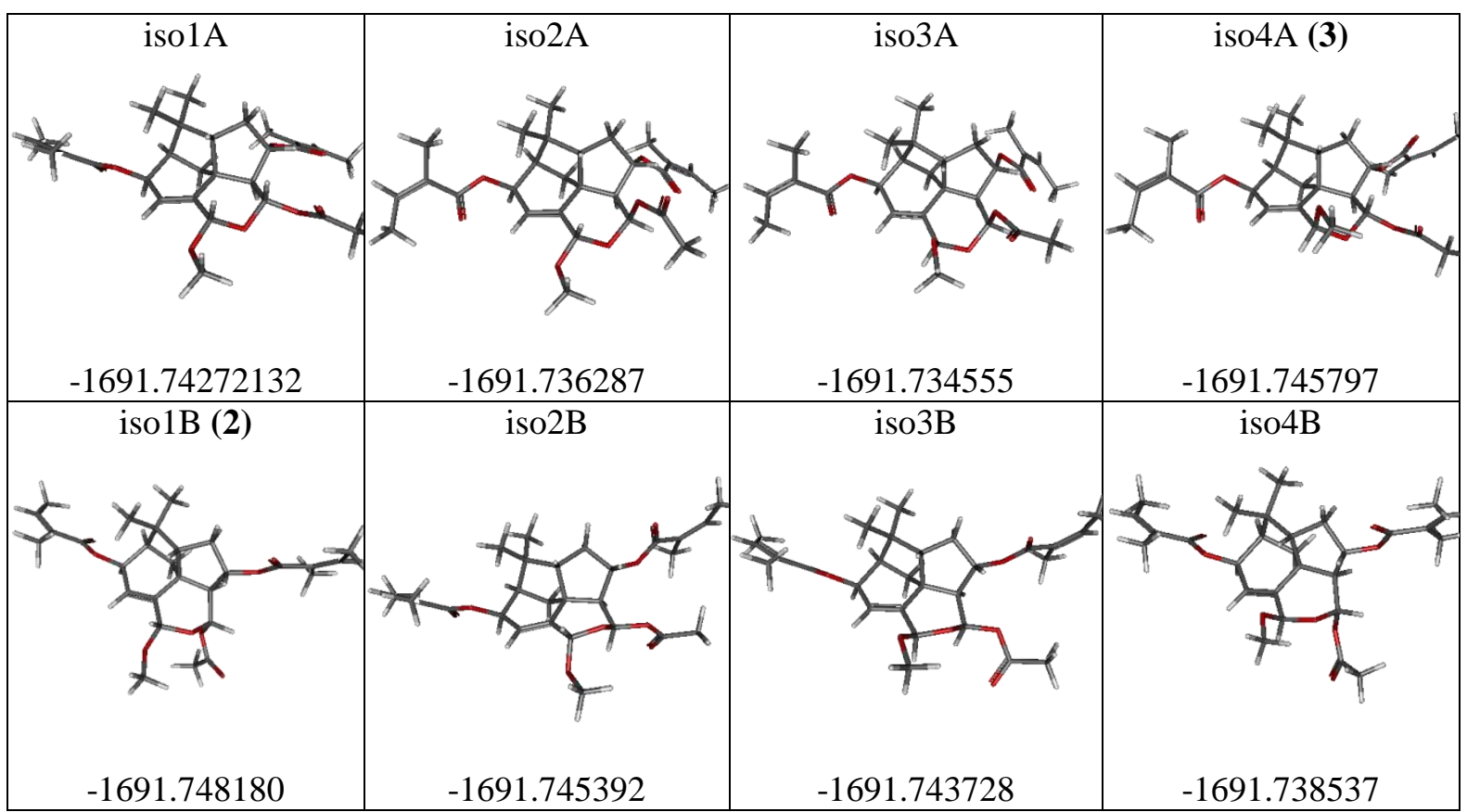

Fig. 4 Optimized geometries and total energies of the eight structures of compound 3 at the B3LYP/6-31+G(d,p) in the gas phase.

The strong NOE effect observed between $\mathrm{H}-14$ and $\mathrm{H}-8$ allows us to retain only isomers where distance between $\mathrm{H}-14$ and $\mathrm{H}-8$ is less than $3 \AA$. The experimental coupling constant between $\mathrm{H}-14$ and $\mathrm{H}-7$ is around $7 \mathrm{~Hz}$; the calculated values which are the most approaching this experimental one are respectively $8.4 \mathrm{~Hz}$ for isomer $1 \mathrm{~A}, 5.9 \mathrm{~Hz}$ for isomer $2 \mathrm{~A}$ and $8.1 \mathrm{~Hz}$ for isomer $4 \mathrm{~A}$, the other values being quite smaller. Furthermore, the root mean square deviations (RMSD) on the calculated ${ }^{13} \mathrm{C}$ chemical shifts has to be less than 2.94 with the chosen method [13]; calculations of the RMSD of the eight isomers provide without any ambiguity the matching of compound $\mathbf{3}$ with isomer $4 \mathrm{~A}$. (Table 3 ). For this structure, where H7 and H-14 are both pseudo axial (Fig. 5), the NOE effect observed between them is puzzling. However, tables SI.4, SI.8 and SI.20 showed that in our conditions, NOE effects could be observed between protons more than $3 \AA$ apart, and calculated distance between $\mathrm{H}-7$ and H-14 is $3.05 \AA$. 
Table 3. Calculated distances between H-14 and H-8, coupling constants between H-14 and $\mathrm{H}-7$, and RMSD obtained on ${ }^{13} \mathrm{C}$ chemical shifts obtained for the eight structures modeled.

\begin{tabular}{r|r|r|r|r|r|r|r|r} 
& iso1A & iso1B (2) & iso2A & iso2B & iso3A & iso3B & iso4A (3) & iso4B \\
\hline $\mathrm{d}(\mathrm{H} 14-\mathrm{H} 8) / \AA$ & $\mathbf{2 . 6 4}$ & $\mathbf{2 . 7 4}$ & $\mathbf{2 . 7 0}$ & 3.72 & $\mathbf{2 . 6 4}$ & 3.70 & $\mathbf{2 . 3 8}$ & $\mathbf{2 . 8 9}$ \\
$J(\mathrm{H} 14-\mathrm{H} 7) / \mathrm{Hz}$ & $\mathbf{8 . 4}$ & 1.7 & $\mathbf{5 . 9}$ & 3.8 & 5.1 & 4.1 & $\mathbf{8 . 1}$ & 1.8 \\
$\mathrm{RMSD} / \mathrm{ppm}$ & 5,70 & 3,25 & 5,98 & 3,16 & 5,92 & 3,10 & $\mathbf{2 , 6 1}$ & 3,78
\end{tabular}

The summary of these DFT-NMR calculations and the comparison with the experimental data are presented in the supplementary information.

Therefore, the structures of $\mathbf{1 , 2}$ and $\mathbf{3}$ proposed (Fig. 1) are confirmed.

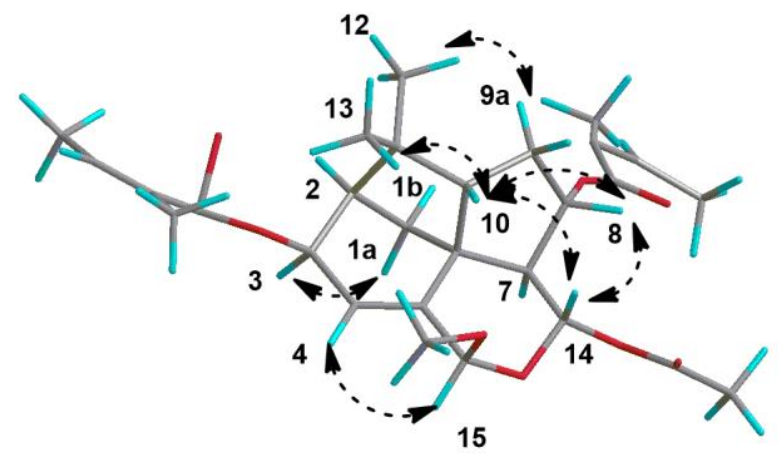

Fig. 5 Key NOESY correlations for compound 3 
Table $1{ }^{13} \mathrm{C}$ NMR Spectroscopic Data (125 MHz, $\left.\mathrm{C}_{6} \mathrm{D}_{6}\right)$ for Compounds 1-4 ( $\delta$ in ppm)

\begin{tabular}{|c|c|c|c|c|c|}
\hline Position & Type & 1 & 2 & 3 & 4 \\
\hline 1 & $\mathrm{CH}_{2}$ & 44.5 & 44.5 & 43.0 & 41.9 \\
\hline 2 & $\mathrm{CH}$ & 52.9 & 52.8 & 52.2 & 53.4 \\
\hline 3 & $\mathrm{CH}$ & 75.9 & 76.2 & 75.9 & 75.6 \\
\hline 4 & $\mathrm{CH}$ & 120.8 & 121.0 & 122.8 & 143.7 \\
\hline 5 & $\mathrm{C}$ & 141.8 & 143.2 & 141.5 & 149.2 \\
\hline 6 & $\mathrm{C}$ & 47.5 & 48.0 & 51.6 & 57.1 \\
\hline 7 & $\mathrm{CH} / \mathrm{C}$ & 49.5 & 50.0 & 51.1 & 149.2 \\
\hline 8 & $\mathrm{CH}$ & 77.5 & 77.5 & 78.1 & 146.6 \\
\hline 9 & $\mathrm{CH}_{2}$ & 33.5 & 33.6 & 34.1 & 33.2 \\
\hline 10 & $\mathrm{CH}$ & 60.5 & 60.6 & 62.0 & 65.2 \\
\hline 11 & $\mathrm{C}$ & 43.2 & 43.3 & 43.9 & 42.9 \\
\hline 12 & $\mathrm{CH}_{3}$ & 28.9 & 29.0 & 29.6 & 29.6 \\
\hline 13 & $\mathrm{CH}_{3}$ & 31.1 & 31.1 & 31.1 & 31.1 \\
\hline 14 & $\mathrm{CH}$ & 90.9 & 90.9 & 89.3 & 188.5 \\
\hline 15 & $\mathrm{CH}$ & 87.5 & 96.5 & 100.9 & 190.9 \\
\hline $1 \% / 1^{\prime \prime b}$ & $\mathrm{CO}$ & 166.9 & 166.9 & 166.8 & 166.5 \\
\hline $1 \% / 1 "$ & $\mathrm{CO}$ & 167.0 & 167.2 & 167.0 & \\
\hline $2^{\prime} / 2^{\prime \prime}$ & $\mathrm{C}$ & 128.1 & 128.0 & 128.1 & 127.6 \\
\hline $2^{\prime} / 2^{\prime \prime}$ & $\mathrm{C}$ & 128.1 & 128.1 & 128.1 & \\
\hline $33^{\prime \prime}$ & $\mathrm{CH}$ & 138.8 & 138.5 & 138.2 & 139.8 \\
\hline $3^{\prime} / 3^{\prime \prime}$ & $\mathrm{CH}$ & 139.2 & 138.8 & 138.9 & \\
\hline $4^{\prime} / 4^{\prime \prime}$ & $\mathrm{CH}_{3}$ & 16.0 & 16.0 & 15.9 & 16.0 \\
\hline $4^{\prime} / 4^{\prime \prime}$ & $\mathrm{CH}_{3}$ & 16.0 & 16.0 & 16.0 & \\
\hline $5^{\prime} / 5^{\prime \prime}$ & $\mathrm{CH}_{3}$ & $20.9^{*}$ & $20.8^{*}$ & 20.7 & 20.9 \\
\hline $5^{\prime} / 5^{\prime \prime}$ & $\mathrm{CH}_{3}$ & $21.0^{*}$ & $21.0^{*}$ & $21.0^{*}$ & \\
\hline \multirow[t]{2}{*}{$14-\mathrm{OAc}$} & $\mathrm{CH}_{3}$ & $20.9^{*}$ & $21.0^{*}$ & $20.9^{*}$ & \\
\hline & $\mathrm{CO}$ & 168.6 & 169.2 & 169.5 & \\
\hline \multirow[t]{2}{*}{$15-\mathrm{OAc}$} & $\mathrm{CH}_{3}$ & 20.6 & & & \\
\hline & $\mathrm{CO}$ & 169.5 & & & \\
\hline $15-\mathrm{OCH}_{3}$ & $\mathrm{CH}_{3}$ & & 55.5 & 55.7 & \\
\hline
\end{tabular}

$a$ : Signals overlap

$b$ : Data do not allow to attribute signals to 3-OAng or 8-OAng in $\mathbf{1 , 2 , 3}$ 
Table $2{ }^{1} \mathrm{H}$ NMR Spectroscopic Data (500 MHz, C6 $\left.\mathrm{D}_{6}\right)$ for Compounds 1-4 ( $\delta$ in ppm)

\begin{tabular}{|c|c|c|c|c|}
\hline Position & 1 & 2 & 3 & 4 \\
\hline \multirow[t]{2}{*}{1} & $1.81^{\mathrm{a}}$ & $1.84^{\mathrm{a}}$ & $1.66 \mathrm{~m}$ & $1.41 \mathrm{dd}(12.2,5.7)$ \\
\hline & $1.91 \mathrm{~m}$ & $1.95^{\mathrm{a}}$ & $2.09^{\mathrm{a}}$ & $2.13 \mathrm{dd}(12.1,2.0)$ \\
\hline 2 & $2.03 \mathrm{~m}$ & $2.11^{\mathrm{a}}$ & $2.08^{\mathrm{a}}$ & $2.04^{\mathrm{a}}$ \\
\hline 3 & $5.96, \mathrm{dt}(4.9,2.5)$ & $5.99 \mathrm{dt}(4.8,2.5)$ & $5.92, \operatorname{ddd}(4.3,2.2,0.8)$ & $5.94 \mathrm{dd}(4.6,2.4)$ \\
\hline 4 & $5.49 \mathrm{q}(2.0)$ & $5.68^{\mathrm{a}}$ & $5.37 \mathrm{se}$ & $5.84 \mathrm{dd}(2.4,1.7)$ \\
\hline 7 & $2.10 \mathrm{dd}(8.8,1.5)$ & $2.11^{\mathrm{a}}$ & $2.30 \mathrm{dd}(7.0,4.2)$ & \\
\hline 8 & $5.20 \mathrm{ddd}(10.5,8.9,5.9)$ & $5.31 \mathrm{ddd}(10.5,8.8,5.9)$ & 5.50 ddd $(7.1,6.1,4.2)$ & $5.86 \mathrm{t}(2.6)$ \\
\hline \multirow[t]{2}{*}{9} & $1.32 \mathrm{~m}$ & $1.40 \mathrm{~m}$ & $1.58 \mathrm{ddd}(13.9,9.9,6.2)$ & $1.92 \mathrm{dd}(9.1,2.5)$ \\
\hline & 2.07 & $2.13^{\mathrm{a}}$ & $2.06^{\mathrm{a}}$ & $1.96 \mathrm{dd}(9.4,2.7)$ \\
\hline 10 & $1.72 \mathrm{~m}$ & $1.89 \mathrm{~m}$ & $2.62 \operatorname{td}(9.6,1.9)$ & $2.34 \operatorname{td}(9.3,1.9)$ \\
\hline 12 & $0.74 \mathrm{~s}$ & $0.78 \mathrm{~s}$ & $0.79 \mathrm{~s}$ & $0.67 \mathrm{~s}$ \\
\hline 13 & $1.19 \mathrm{~s}$ & $1.27 \mathrm{~s}$ & $1.33 \mathrm{~s}$ & $1.10 \mathrm{~s}$ \\
\hline 14 & $6.45 \mathrm{~d}(1.4)$ & $6.41 \mathrm{~d}(1.7)$ & $6.43 \mathrm{~d}(7.0)$ & $9.62 \mathrm{~s}$ \\
\hline 15 & $6.92 \mathrm{dd}(2.8,2.0)$ & $4.96 \mathrm{dd}(2.7,1.9)$ & $4.91 \mathrm{se}$ & $9.09 \mathrm{~s}$ \\
\hline $3^{\prime} / 3^{\prime \prime}$ & $5.71 \mathrm{~m}$ & $5.70 \mathrm{~m}$ & $5.70 \mathrm{~m}$ & $5.77 \mathrm{qq}(7.3,1.5)$ \\
\hline $3^{\prime} / 3^{\prime \prime}$ & $5.71 \mathrm{~m}$ & $5.70 \mathrm{~m}$ & $5.70 \mathrm{~m}$ & \\
\hline $4^{\prime} / 4^{\prime \prime}$ & $1.99 \mathrm{dq}(7.3,1.5)$ & $2.00 \mathrm{dq}(7.2,1.5)$ & $2.03 \mathrm{dq}(7.2,1.6)$ & $2.04 \mathrm{dq}(7.2,1.5)$ \\
\hline $4^{\prime} / 4^{\prime \prime}$ & $1.96 \mathrm{dq}(7.2,1.5)$ & $1.95 \mathrm{dq}(7.2,1.6)$ & $1.97 \mathrm{dq}(7.2,1.5)$ & \\
\hline $5^{\prime} / 5^{\prime \prime}$ & $1.82^{\mathrm{a}}$ & $1.82^{\mathrm{a}}$ & $1.82 \mathrm{~m}$ & $1.82 \mathrm{p}(1.5)$ \\
\hline $5^{\prime} / 5^{\prime \prime}$ & $1.82^{\mathrm{a}}$ & $1.82^{\mathrm{a}}$ & $1.82 \mathrm{~m}$ & \\
\hline 14-OAc & $1.70 \mathrm{~s}$ & $1.74 \mathrm{~s}$ & $1.71 \mathrm{~s}$ & \\
\hline $15-\mathrm{OAc}$ & $1.59 \mathrm{~s}$ & & & \\
\hline 15-OMe & & $3.27 \mathrm{~s}$ & $3.36 \mathrm{~s}$ & \\
\hline
\end{tabular}

${ }^{\text {aSignals overlapped }}$

Antiparasitic activity of compounds 1, 2, 3 and $\mathbf{4}$ was evaluated on P. falciparum and Leishmania infantum axenic amastigotes following already published protocols. To assess the selectivity of their antiparasitic activity, their toxicity on J774A.1 macrophages or THP-1 cells was evaluated. Results are reported in Table 4. The bioguided fractionation process which allows the isolation of $1,2,3$ and 4 was based on the activity of the ethanolic extract of $P$. multiflora on in vitro culture of $P$. falciparum $\left(\mathrm{IC}_{50}=4 \mu \mathrm{g} / \mathrm{mL}\right)$. The ethyl acetate fraction, obtained after partition of ethanolic extract between ethyl acetate and water was further partionned between petroleum ether and methanol. The methanol fraction was showed to 
concentrate the biological activity ( $\mathrm{IC}_{50}=0.8 \mu \mathrm{g} / \mathrm{mL}$ ). Only compound 4 displayed a slightly better antiplasmodial activity than the methanol fraction $\left(\mathrm{IC}_{50}=0.8 \mu \mathrm{M}\right.$ or $0.26 \mu \mathrm{g} / \mathrm{mL}$ ) suggesting that some others compounds contribute to the activity of the extract. Compound 4 was the only one to present small selectivity against mammalian with a SI of 5. Compounds showed only moderate activity against $P$. falciparum, and displayed no selectivity. This work is the first report of antiplasmodial activity and cytotoxic activity of isocedrenes or trixanes. These compounds displayed better activity on L. infantum axenic amastigotes, but in the same range than their toxicity on J774A.1 macrophages. Antileishmanial activity of one trixane isolated from Trixis antimenorrhoea has already been reported on promastigotes of L. infantum and L. amazonensis [12].

Table 4 Biological activity of compounds 1-4 (IC50 values in $\mu \mathrm{M})$

\begin{tabular}{|c|c|c|c|c|}
\hline Compounds & P.falciparum & $\begin{array}{c}\text { L.infantum axenic } \\
\text { amastigotes }\end{array}$ & $\begin{array}{c}\text { Mouse macrophages } \\
\text { J774A.1 }\end{array}$ & THP-1 cells \\
\hline $\mathbf{1}$ & $16.4(+/-0.7)$ & $1.55(+/-0.15)$ & $0.51(+/-0.06)$ & NT \\
\hline $\mathbf{2}$ & $7.6(+/-0.3)$ & $2.01(+/-0.19)$ & $0.86(+/-0.03)$ & NT \\
\hline $\mathbf{3}$ & $3.9(+/-0.8)$ & $0.16(+/-0.01)$ & $0.16(+/-0.01)$ & NT \\
\hline $\mathbf{4}$ & $0.81(+/-0.1)$ & NT & NT & $2.6(+/-0.09)$ \\
\hline Chloroquine & $0.08(+/-0.0)$ & NT & NT & NT \\
\hline Amphotericin B & NT & $0.055(+/-0.08)$ & NT & NT \\
\hline Doxorubicin & NT & NT & $0.023(+/-0.004)$ & $2.33(+/-0.2)$ \\
\hline
\end{tabular}

\section{Conclusion}

In this work, we describe four isocedrenes isolated from $P$. multiflora, a highly valued herbal remedy in the andean mountains. One of them, compound $\mathbf{2}$ is new. Compound $\mathbf{1}$ was already isolated from $P$. multiflora and compound 3 from $P$. runcinata, but carefull examination of their NMR data, together with calculation of stability of their conformers and prediction of their NMR spectra allowed us to propose revised 3D structure for both of them. This work highlight the influence of the substitution of the tetrahydropyranose ring of isocedrenes on their more stable conformation and therefore on NMR spectra. This is here the 
first report of biological activity of isocedrene sesquiterpenes. Their antiparasitic activity is not selective enough, but it could be interesting to evaluate their cytotoxicity on cancerous cells lines. As isocedrenes appeared here as potentially toxic molecules, it would be interesting to evaluate their concentration in traditional preparations made with $P$. multiflora, to assess the safety of use of this herbal remedy.

\section{Materials and methods}

\section{Chemical and reagents}

Ethanol (96\%) was from Laboratoire ALKOFARMA E.I.R.L, (Lima, Pérou). Petroleum ether, cyclohexane, dichloromethane, ethyl acetate, methanol, were of analytical or HPLC grade and bought from Fisher Scientific SAS. Merck Silica gel $60(15-40 \mu \mathrm{m})$ was used for medium pressure column chromatography (MPLC). Analytical thin-layer chromatography was achieved on precoated silica gel plates (Merck, Kieselgel $60 \mathrm{~F}_{254}, 0.25 \mathrm{~mm}$ ) using UV 254 nm and a $1 \%$ vanillin/ $10 \% \mathrm{H}_{2} \mathrm{SO}_{4}$ reagent in ethanol for visualization.

\section{General procedures}

MPLC column were run with Büchi medium pressure glass columns of various sizes, with a Büchi pump manager C-615 connected to a Büchi pump module C-601. Optical rotations were determined with a JASCO P2000 digital polarimeter. CD spectra were recorded on a JASCO J-815, at $20^{\circ} \mathrm{C}$, with a measurement range of $190-280 \mathrm{~nm}$, a data interval of $0.2 \mathrm{~nm}$, a bandwidth of $1 \mathrm{~nm}$ and a scanning speed of $20 \mathrm{~nm} / \mathrm{min}$, at a concentration of $7.75 \mathrm{ppm}$. The NMR spectra were recorded on a Bruker Avance $500 \mathrm{MHz}$ instrument with samples diluted in $\mathrm{C}_{6} \mathrm{D}_{6}\left(\delta_{\mathrm{H}} 7.16\right.$ and $\left.\delta_{\mathrm{C}} 128.06\right)$ or on a Bruker Avance $300 \mathrm{MHz}$ instrument with samples diluted in $\mathrm{CDCl}_{3}\left(\delta_{\mathrm{H}} 7.28\right.$ and $\left.\delta_{\mathrm{C}} 77.1\right)$. UHPLC/MS analysis was performed using a UHPLC Ultimate 3000 system (Dionex) controlled by Chromeleon Xpress 6.8 software (Dionex), coupled with an LTQ Orbitrap XL mass spectrometer (Thermo Fisher Scientific). All spectra were acquired and processed using LCQ Xcalibur 3.0 software (Thermo Fisher Scientific). 


\section{Plant material}

Perezia multiflora (Bonpl.) Less. was purchased as a whole fresh plant in the Challwa market (town of Huaraz, Peru) in august 2017. A voucher specimen was deposited at the national herbarium of the museum of natural history (Universidad Mayor Nacional San Marcos, Lima, Peru, deposit $\mathrm{N}^{\circ}$ 026-2018-USM-MHN), where it was identified by specialists. Whole plant was dried at ambient temperature in a ventilated place away from the sun. Aerial parts and roots were separated, and aerial parts were grinded.

\section{Extraction and isolation of pure compounds}

Grinded aerial plant (375 g) was extracted successively three times in $3.3 \mathrm{~L}$ of EtOH $96 \%$ at ambient temperature during $12 \mathrm{~h}$. Filtrates were pooled together and solvent was evaporated under reduced pressure to give $53 \mathrm{~g}$ of extract. This extract was partitioned between $1 \mathrm{~L}$ of ethyl acetate and $1 \mathrm{~L}$ of water. A white precipitate was removed and ethyl acetate phase was separated. The solvent was removed under reduced pressure to give $20.4 \mathrm{~g}$ of ethyl acetate extract. This extract was further partitioned between $400 \mathrm{~mL}$ of petroleum ether and $400 \mathrm{~mL}$ of methanol containing $10 \%$ of water. After removal of solvents under reduced pressure, $7.9 \mathrm{~g}$ of petroleum ether extract and $10.3 \mathrm{~g}$ of methanol extract were obtained.

Purification of compounds 1-3: Methanol extract (5 g) was submitted to MPLC (diameter of column: $4 \mathrm{~cm}$, packed with $65 \mathrm{~g}$ of silica). Column was eluted with dichloromethane containing

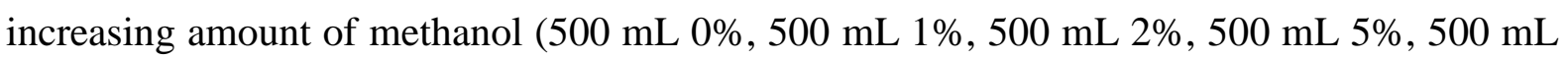
$10 \%$ and $300 \mathrm{~mL} \mathrm{100 \% )} \mathrm{and} 25 \mathrm{~mL}$ fractions were collected. Based on TLC analysis, the eluted fractions were pooled into six fractions (F1 - F6) of which each was tested in the $P$. falciparum assay. Fraction $2(546 \mathrm{mg})$, displayed the best activity against $P$. falciparum $\left(\mathrm{IC}_{50}=0.4\right.$ $\mu \mathrm{g} / \mathrm{mL}$ ). Fraction $2(520 \mathrm{mg}$ ) was submitted to MPLC (diameter of column: $3 \mathrm{~cm}$, packed with $35 \mathrm{~g}$ of silica). Column was eluted with petroleum ether containing increasing amount of ethyl 


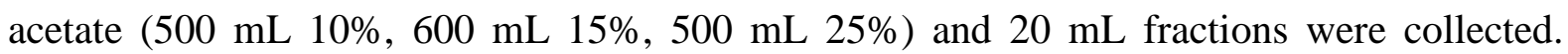
Fractions were pooled according to their TLC profiles and 8 fractions were obtained (F2-1 F2-8). F2-4 (110 mg) was submitted to size exclusion chromatography (10 g of Sephadex ${ }^{\circledR}$ LH-20 conditioned with methanol in a $1 \mathrm{~cm}$ diameter glass column). Column was eluted with methanol, $2 \mathrm{~mL}$ fractions were collected, and pooled according to their TLC profile to give compound 1 ( $89 \mathrm{mg})$. F2-1 (18.5 mg) was treated with the same protocol to give compound $\mathbf{3}$ (10.7 mg). F2-2 (37.8 mg) was submitted to size exclusion chromatography (1 g of Sephadex ${ }^{\circledR}$ LH-20 conditioned with methanol in a $1 \mathrm{~cm}$ diameter column). Column was eluted with methanol, $0.5 \mathrm{~mL}$ fractions were collected, and pooled according to their TLC profile to give compound 2 (26.3 mg). F2-3 (35 mg) was treated with the same protocol to give 2 fractions (F2-3-1, and F2-3-2).

Purification of compound 4: Methanol extract (5 g) was submitted to the same column chromatography as described above. Fractions pooling was slightly different and gave 8 fractions (F1' - F8'). Fractions F2' (281 mg) and F3' (302 mg) displayed the best activity against $P$. falciparum $\left(\mathrm{IC}_{50}=0.23 \mu \mathrm{g} / \mathrm{mL}\right.$ and $0.7 \mu \mathrm{g} / \mathrm{mL}$ respectively). F2' was submitted to MPLC (diameter of column: $2.5 \mathrm{~cm}$, packed with $35 \mathrm{~g}$ of silica). Column was eluted with cyclohexane containing increasing amount of ethyl acetate $(500 \mathrm{~mL} \mathrm{10 \% ,600} \mathrm{mL} \mathrm{15 \% ,} 500$ $\mathrm{mL} 25 \%, 350 \mathrm{~mL} 50 \%$ ) and $20 \mathrm{~mL}$ fractions were collected. Fractions were pooled according to their TLC profiles and 5 fractions were obtained (F2-1' - F2-5'). F2-2' (76.3 mg) was further purified with size exclusion chromatography (40 g of Sephadex® LH-20 conditioned with methanol in a $2 \mathrm{~cm}$ diameter glass column). Column was eluted with methanol, $2 \mathrm{~mL}$ fractions were collected, and pooled according to their TLC profile to give compound 4 (23.7 $\mathrm{mg})$.

Compound 1: colorless oil, $\mathrm{R}_{\mathrm{f}}$ 0.40, silica gel 60 F254, Petroleum ether/AcOEt $(80: 20) ;[\alpha]_{D}^{20}$ $+22.5\left(\mathrm{c} 0.475, \mathrm{CH}_{2} \mathrm{Cl}_{2}\right), \mathrm{CD}\left(\mathrm{CH}_{3} \mathrm{CN}\right) \Delta \varepsilon_{204.8}+21.1, \Delta \varepsilon_{227.8}-5.4 ;{ }^{1} \mathrm{H}$ and ${ }^{13} \mathrm{C}$ NMR : see tables 
1, 2 for data in $\mathrm{C}_{6} \mathrm{D}_{6}$ and table SI.21 for data in $\mathrm{CDCl}_{3}$. HR ESIMS (pos. ion mode) $\mathrm{m} / \mathrm{z}$ 548.2856, $\left[\mathrm{M}+\mathrm{NH}_{4}\right]^{+}\left(\right.$calcd for $\left.\mathrm{C}_{29} \mathrm{H}_{42} \mathrm{NO}_{9} 548.2854\right)$

Compound 2: colorless oil, $\mathrm{R}_{\mathrm{f}}$ 0.60, silica gel 60 F254, Petroleum ether/AcOEt $(80: 20) ;[\alpha]_{D}^{20}$ $+3.0\left(\mathrm{c} 0.43, \mathrm{CH}_{2} \mathrm{Cl}_{2}\right), \mathrm{CD}\left(\mathrm{CH}_{3} \mathrm{CN}\right) \Delta \varepsilon_{206.2}+25.5, \Delta \varepsilon_{227.4}-7.6 ;{ }^{1} \mathrm{H}$ and ${ }^{13} \mathrm{C}$ NMR : see tables $\mathbf{1}$, 2 for data in $\mathrm{C}_{6} \mathrm{D}_{6}$ and table SI.21 for data in $\mathrm{CDCl}_{3}$. HR ESIMS (pos. ion mode) $\mathrm{m} / z$ 525.2457, $[\mathrm{M}+\mathrm{Na}]^{+}$(calcd for $\left.\mathrm{C}_{28} \mathrm{H}_{38} \mathrm{O}_{8} \mathrm{Na} 525.2459\right)$

Compound 3: colorless oil, $\mathrm{R}_{\mathrm{f}}$ 0.65, silica gel 60 F254, Petroleum ether/AcOEt $(80: 20) ;[\alpha]_{D}^{20}$ -38.2 (c 0.75, $\left.\mathrm{CH}_{2} \mathrm{Cl}_{2}\right), \mathrm{CD}\left(\mathrm{CH}_{3} \mathrm{CN}\right) \Delta \varepsilon_{204.4}+25.3, \Delta \varepsilon_{224.8}-7.9 ;{ }^{1} \mathrm{H}$ and ${ }^{13} \mathrm{C}$ NMR : see tables 1, 2 for data in $\mathrm{C}_{6} \mathrm{D}_{6}$ and table SI.21 for data in $\mathrm{CDCl}_{3}$. HR ESIMS (pos. ion mode) $\mathrm{m} / \mathrm{z}$ 525.2458, $[\mathrm{M}+\mathrm{Na}]^{+}\left(\right.$calcd for $\left.\mathrm{C}_{28} \mathrm{H}_{38} \mathrm{O}_{8} \mathrm{Na} 525.2459\right)$

Compound 4: colorless oil, $\mathrm{R}_{\mathrm{f}}$ 0.36, silica gel 60 F254, Petroleum ether/AcOEt (80:20); ${ }^{1} \mathrm{H}$ and ${ }^{13} \mathrm{C}$ NMR : see tables $\mathbf{1 ,} 2$ for data in $\mathrm{C}_{6} \mathrm{D}_{6}$. HR APCIMS (pos. ion mode) $\mathrm{m} / z$ 329.1742, $[\mathrm{M}+\mathrm{H}]^{+}\left(\right.$calcd for $\left.\mathrm{C}_{20} \mathrm{H}_{25} \mathrm{O}_{4} 329.1747\right)$

\section{Biological assays} [15].

Protocols for antiplasmodial and antileishmanial activity assays were already described

\section{Cytotoxicity evaluation on J774A.1}

The evaluation of the tested molecules cytotoxicity by MTT assay was done on the J774A.1 cell line (mouse macrophage cell line, Sigma-Aldrich). Briefly, cells $\left(5.10^{4}\right.$ cells $\left./ \mathrm{mL}\right)$ in $100 \mu \mathrm{L}$ of complete medium, [DMEM High glucose supplemented with $10 \%$ fetal calf serum (FCS), $2 \mathrm{mM}$ L-glutamine and antibiotics (100U/mL penicillin and $100 \mu \mathrm{g} / \mathrm{mL}$ streptomycin)] were seeded into each well of 96-well plates and incubated at $37{ }^{\circ} \mathrm{C}$ in a humidified $5 \% \mathrm{CO}_{2}$ with $95 \%$ air atmosphere. After a $24 \mathrm{~h}$ incubation, $100 \mu \mathrm{L}$ of medium with various product or extracts concentrations and appropriate controls were added and the plates were incubated for $72 \mathrm{~h}$ at 37 
${ }^{\circ} \mathrm{C}$. Each plate-well was then microscope-examined for detecting possible precipitate formation before the medium was aspirated from the wells. $100 \mu \mathrm{L}$ of MTT solution $(0.5 \mathrm{mg} / \mathrm{mL}$ in RPMI $)$ were then added to each well. Cells were incubated for $2 \mathrm{~h}$ at $37^{\circ} \mathrm{C}$. After this time, the MTT solution was removed and DMSO $(100 \mu \mathrm{L})$ was added to dissolve the resulting formazan crystals. Plates were shaken vigorously (300 rpm) for $5 \mathrm{~min}$. The absorbance was measured at $570 \mathrm{~nm}$ with a microplate spectrophotometer. DMSO or $\mathrm{MeOH}$ was used as blank and doxorubicin (purchased from Sigma Aldrich) as positive control. $\mathrm{CC}_{50}$ were calculated by non-linear regression analysis processed on dose-response curves, using TableCurve 2D V5 software.

\section{Cytotoxicity evaluation on THP-1}

The evaluation of the tested molecules cytotoxicity by MTT assay was done on the THP-1 cell line (human monocyte cell line). Briefly, cells $\left(0.77 .10^{5}\right.$ cells $\left./ \mathrm{mL}\right)$ in $200 \mu \mathrm{L}$ of complete medium [RPMI 1640 supplemented with 10\% fetal calf serum (FCS), 2 mM L-glutamine and antibiotics (100U/mL penicillin and $100 \mu \mathrm{g} / \mathrm{mL}$ streptomycin $)]+$ PMA $(50 \mathrm{ng} / \mathrm{ml})$ were seeded into each well of 96-well plates and incubated at $37{ }^{\circ} \mathrm{C}$ in a humidified $5 \% \mathrm{CO}_{2}$ with $95 \%$ air atmosphere. After a 96h incubation, Plates were rinse 3 times with medium and $100 \mu 1$ of medium were added. 100 $\mu \mathrm{L}$ of medium with various product or extracts concentrations and appropriate controls were added and the plates were incubated for $72 \mathrm{~h}$ at $37^{\circ} \mathrm{C}$. Further treatment of the plates was as described above for J774A. 1 macrophages.

\section{Supporting information}

Detailed results of DFT calculations and NMR modelisations for compounds 1, 2, 3: geometries, total energies, enthalpies and Boltzmann distribution ; experimental $\left(\mathrm{CDCl}_{3}\right)$ and calculated ${ }^{13} \mathrm{C}$ chemical shifts in the chloroform PCM continuum model (SMD), and RMSD value ; calculated

${ }^{1} \mathrm{H}$ chemical shifts and coupling constants for the major conformers ; experimental NOE effects and distances observed on the major conformers ; ${ }^{1} \mathrm{H}$ spectrum simulated at $300 \mathrm{MHz}$ using 
MestReNova software compared to experimental one in $\mathrm{CDCl}_{3}$; Table of ${ }^{1} \mathrm{H}$ and ${ }^{13} \mathrm{C}$ NMR data in $\mathrm{CDCl}_{3}$ for compounds $\mathbf{1 , 2 , 3} ; 1 \mathrm{D}$ and $2 \mathrm{D}$ spectra of compounds $\mathbf{1 , 2}, \mathbf{3}$ in $\mathrm{C}_{6} \mathrm{D}_{6}$.

\section{Acknowledgements}

The authors thank the logistic support of the LMI-LaVi (UPCH-IRD, Lima, Peru) and their directors : Pr. Rosario Rojas (UPCH) and Dr. Michel Sauvain (IRD). The authors are grateful to Pierre Lavedan, Marc Vedrenne and Caroline Toppan (NMR platform of the Institut de Chimie de Toulouse, ICT) for NMR analyses and to Dr Stéphane Massou (NMR platform of the Institut de Chimie de Toulouse, ICT) for fruitful discussions and help with the redaction of the SI section. The authors thank Dr Charles-Louis Serpentini (IMRCP, UMR 5623 CNRS-Université Toulouse 3) for the recording of $\mathrm{CD}$ spectra. The authors are indebted to the personnel of Universidad Nacional Mayor San Marcos, Lima, Peru, (UNMSM) herbarium for plant determination and the Servicio Nacional Forestal y de Fauna Silvestre (SERFOR) for issuing the P. multiflora collecting and research permits (No 406-2016-SERFOR/DGGSPFFS and No 80-2017-SERFOR/DGGSPFFS).

\section{Conflict of Interest}

The authors declare no conflict of interest

\section{References}

1 Bohlmann F, Zdero C. Neue sesquiterpene mit anomalem Kohlenstoffgerust aus der tribus Mutisieae. Chemische berichte 1979; 112: 427-434

2 Bohlmann F, Zdero C. Uber eine neue gruppe von sesquiterpenlactonene aus der Gattung Trixis. Chemische berichte 1979; 112: 435-444

3 Bohlmann F, Zdero C, King RM, Robinson H. A tetracyclic sesquiterpene, further isocedrene, and guaiene derivatives from Jungia stuebelii. Phytochemistry 1983; 22: $1201-1206$

4 Singh P, Jakupovic J, Bohlmann F. Isocedrene derivatives and other sesquiterpenes from Moscharia pinnatifida. Phytochemistry 1985; 24: 1525-1529 
Zdero C, Bohlmann F, Niemeyer HM. Isocedrene and guaiane derivatives from Pleocarphus revolutus. Journal of natural products 1988; 51: 509-512 Zdero C, Bohlmann F, Sanchez H, Dominguez XA. Isocedrene derivatives and other constituents from Acourtia nana. Phytochemistry 1991; 30: 2695-2697 Zdero C, Bohlmann F, King RM, Robinson H. $\alpha$-Isocedrene derivatives, 5-methyl coumarins and other constituents from the subtribe Nassauviinae of the Compositae. Phytochemistry 1986; 25: 2873-2882

De Riscala EC, Catalan CAN, Sosa VE, Gutierrez AB, Herz W. Trixane derivatives from Trixis praestans. Phytochemistry 1988; 27: 2343-2346 Ybarra MI, Catalan CAN, Diaz JG, Herz W. A cyperane and trixanes from Jungia polita. Phytochemistry 1992; 31: 3627-3629 Azevedo L, Faqueti L, Kritsanida M, Efstathiou A, Smirlis D, Franchi GCJ, GentaJouve G, Michel S, Sandjo LP, Grougnet R, Biavatti MW. Three new trixane glycosides obtained from the leaves of Jungia sellowii less. using centrifugal partition chromatography. Beilstein Journal of Organic chemistry 2016; 12: 674-683 Kotowicz C, Hernandez LR, Cerda-Garcia-Rojas CM, Villecco MB, Catalan CAN, Joseph-Nathan P. Absolute configuration of trixanolides from Trixis pallida. Journal of Natural Products 2001; 64: 1326-1331 Maldonadoa EM, Salamanca E, Gimenez A, Saavedra G, Sterner O. Antileishmanial metabolites from Trixis antimenorrhoea. Phytochemistry Letters 2014; 10: 281-286 Zdero C, Bohlmann F, Solomon J, Dominguez XA. Further isocedrene derivatives and other constituents from Perezia species. Phytochemistry 1988; 27: 849-853 Lodewyk MW, Siebert MR, Tantillo DJ. Computational Prediction of $1 \mathrm{H}$ and 13C Chemical Shifts: A Useful Tool for Natural Product, Mechanistic, and Synthetic Organic Chemistry. Chemical Reviews 2012; 112: 1839-1862 

Bourdy G, Jullian V. Structural Characterization and Anti-infective Activity of 9,10Seco-29-norcycloartane Glycosides Isolated from the Flowers of the Peruvian Medicinal Plant Cordia lutea. Journal of natural products 2019; 82: 3233-3241 